$\mathcal{H a l}: 1-4$

\title{
PERAN LEMBAGA BANTUAN HUKUM PERGURUAN TINGGI YAYASAN UNIVERSITAS LABUHANBATU
}

\author{
TONI \\ Prodi Pendidikan PKn STKIP Labuhan Batu \\ Email: toni300586@gmail.com
}

Diterima Februari 2018 dan Disetujui Maret 2018

\begin{abstract}
ABSTRAK
Lembaga Bantuan Hukum Perguruan Tinggi Yayasan Universitas Labuhanbatu (Y-ULB) sangat penting keberadaanya ditengah-tengah masyarakat, mengingat prinsip persamaan di mata hukum atau sesuai dengan amanah Undang-undang Dasar Pasal 1 ayat (3) menyatakan bahwa. "Negara Indonesia adalah negara hukum". dan selanjutnya Pasal 27 ayat (1) UUD 1945 menyatakan bahwa. "Setiap Warga Negara bersamaan kedudukannya di dalam hukum dan pemerintahan wajib menjunjung hukum dan pemerintahan itu dengan tidak ada kecualinya". Sebagian besar dari masyarakat kita masih hidup dibawah garis kemiskinan, minimnya pengetahuan hukum bagi masyarakat merupakan hambatan dalam menerapkan hukum di masyarakat. Terlebih lagi budaya hukum dan tingkat kesadaran hukum yang sangat rendah. Lembaga bantuan hukum juga diatur didalam peraturan perundang-undangan diantaranya, undang-undang No. 16 tahun 2011 Tentang Bantuan Hukum, undang-undang No.48 Tahun 2009 Tentang Kekuasaan Kehakiman, undang-undang No.18 Tahun 2003 Tentang Advokat, undang-undang No. 8 Tahun 1981 Tentang Hukum Acara Pidana. Lembaga bantuan hukum perguruan tinggi tersebut diharapkan dapat bermitra dengan Pemerintah dan instansi-instasi penegak hukum yang lain, guna menambah penunjang kenerja LBH Perguruan Tinggi yang lebih propisional dalam penegakan hukum.
\end{abstract}

Kata Kunci: Peran Lembaga Bantuan Hukum Perguruan Tinggi YULB, Masyarakat.

\section{PENDAHULUAN}

Bahwa Keberadaan Lembaga

Bantuan Hukum Perguruan Tinggi Yayasan Universitas Labuhanbatu ( Y-ULB) sangat penting keberadanya ditengah-tengah masyarakat mengingat prinsip persamaan dimata hukum atau sesuai dengan amanah Undang-Undang Dasar Pasal 1 ayat (3) menyatakan bahwa, Negara Indonesia adalah negara hukum". Selanjutnya Pasal 27 ayat (1) UUD 1945 menyatakan bahwa "Setiap Warga Negara bersamaan kedudukannya di dalam hukum dan pemerintahan wajib menjunjung hukum dan pemerintahan itu dengan tidak ada kecualinya". Apalagi dengan sebagian besar anggota masyarakat kita masih hidup dibawah garis kemiskinan, dan minimnya pengetahuan hukum masyarakat juga merupakan hambatan dalam menerapkan hukum dalam masyarakat. Terlebih lagi budaya hukum dan tingkat kesadaran hukum yang sangat rendah di Indonesia. Lembaga Bantuan Hukum selain karena mengusung konsep baru dalam pelaksanaan program bantuan hukum di Indonesia, Lembaga Bantuan Hukum juga dianggap sebagai cikal bakal bantuan hukum yang terlembaga yang dikatakan paling berhasil pada masanya. Hingga pendirian Lembaga Bantuan Hukum ini kemudian mendorong tumbuhnya berbagai macam dan bentuk organisasi dan wadah bantuan hukum di Indonesia.

Kesadaran dan pemahaman hukum masyarakat yang rendah ini dapat berupa ketidakmengertian masyarakat akan hukum yang berlaku maupun karena ketidaktahuan mereka atas bantuan hukum yang merupakan hak dari orang miskin yang dapat diperoleh tanpa bayar (pro bono publico) sehingga setiap orang dapat memperoleh haknya untuk mendapatkan layanan hukum, selama ini yang sering kita dengar hanya orang kaya yang mampu untuk berperkara ketika terjadi persolan hukum dan bisa menyewa jasa pengacara, sedangkan masyarakat miskin hanya isapan jempol untuk menyelesaikan 
persolan hukum dikarenakan keterbatasan finansial keungan jika menyewa jasa pengacara. Profesi advokat sesungguhnya dikenal sebagai profesi yang mulia (Officium Mobile), karena mewajibkan pembelaan kepada semua orang tanpa membedakan latar belakang ras, warna kulit, agama, budaya, dan sosial ekonomi. Peran Profesi Advokat bukan sekedar mencari nafkah semata, tetapi juga harus memperjuangkan nilai idealisme dan moralitas.

Istilah legal assistance dipergunakan untuk menunjuk pengertian bantuan hukum yang diberikan baik kepada mereka yang tidak mampu yang diberikan secara cumacuma maupun pemberian bantuan hukum oleh para penasehat hukum yang mempergunakan Honorarium. Bantuan Hukum yang diberikan oleh Perguruan Tinggi Yayasan universitas Labuhanbatu (Y-ULB) tidak terlepas dari Lembaga Bantuan Hukum. Sejarah dan perkembangan bantuan hukum di Indonesia tak lepas dari peran serta lembaga ini, meskipun sudah ada undangundang tersendiri tentang bantuan hukum, pada undang-undang No. 16 Tahun 2016, juga diatur dalam Peraturan Pemerintah Republik Indonesia No.83 Tahun 2008 tentang Persyaratan dan Tata Cara Pemberian Bantuan Hukum Secara CumaCuma memberikan pengerian dari lembaga ini, yang diatur dalam pasal 1 angka 6, dimana dikatakan bahwa Lembaga Bantuan Hukum adalah lembaga yang memberikan bantuan hukum kepada pencari keadilan tanpa menerima pembayaran honorarium.

Tujuan dan fungsi LBH Perguruan Tinggi didirikan dengan konsep awal melindungi masyarakat dari penindasan hukum yang kerap menimpa Masyarakat yang lemah. Konsep ini kemudian dituangkan dalam Anggaran Dasar LBH yang didalamnya disebutkan:

1. Memberi pelayanan hukum kepada rakyat miskin

2. Mengembangkan dan meningkatkan kesadaran hukum rakyat, terutama mengenai hak-haknya sebagai subjek hukum

3. Memberikan perubahan dan perbaikan hukum untuk mengisi kebutuhan baru dari masyarakat yang berkembang.

Harapanya Bantuan Hukum

Perguruan Tinggi Yayasan Universitas
Labuhanbatu dapat memberikan kontribusi yang besar kepada masyarakat luas dalam memberikan bantuan hukum kepada masyarakat yang ingin mencari keadilan. Dalam memberikan bantuan hukum harus menjunjung tinggi nilai-nilai keadilan dan moralitas selaku profesi yang profesional.

\section{METODE PENELITIAN \\ Tempat Penelitian}

Penelitian ini dilaksanakan di Kantor Lembaga Bantuan Hukum Yayasan Universitas Labuhan Batu Kabupaten Labuhan Batu Provinsi Sumatera Utara

\section{Waktu Penelitian}

Penelitian ini dilaksanakan bulan Desember 2017 sampai dengan Januari 2018

\section{Jenis Penelitian}

Penelitian ini menggunakan jenis penelitian kualitatif dengan metode deskriptif analisis, yakni metode yang menjelaskan mengenai suatu fakta atau fenomena hukum, dengan mendeskripsikan untuk memecahkan masalah yang berkenaan dengan masalah yang akan diteliti.

\section{Sumber Data}

1. Data Primer, yaitu data yang diperoleh secara langsung dari observasi saat penelitian berupa melakukan wawancara kepada pengurus Bantuan Hukum Perguruan Tinggi Yayasan Universitas Labuhanbatu dengan menganalisis data yang didapatkan dari risponden.

2. Data Sekunder, yaitu data yang diperoleh secara tidak langsung melalui penelitian kepustakaan (library research) berupa mengumpulkan referensi berupa buku-buku, kaya tulis ilmia, artikel-artikel dari internet serta dokumen-dokumen dianggap penting masalah dibahas untuk penelitian.

\section{Teknik Pengumpulan Data}

Data Penelitian ini, penulis akan menyaring sebagai bahan analisis dengan menggunakan teknik sebagai berikut:

a. Observasi (pengamatan), kegiataan observasi yang dilakukan oleh peneliti diperoleh data sementara yaitu menghayati peran dari 
Perguruan tinggi Labuhanbatu dalam memberikan bantuan.

b. Wawancara (interview) awal, peneliti memperoleh data sementara, Wawancara bertujuan untuk memperoleh pengetahuan tentang makna-makna subyektif yang dipahami individu berkenaan dengan topik yang diteliti.

c. Dokumentasi diperoleh data primer berupa gambar, Pengumpulan data dengan dokumen merupakan pelengkap dari penggunaan metode observasi dan wawancara dalam penelitian kualitatif.

\section{Analisis data}

Setelah data diperoleh dan dikumpulkan, data tersebut dipelajari dan diklasifikasikan sesuai dengan pokok masalah. Kemudian dibahas dengan cara analisis kualitatif yaitu dengan cara mendiskripsikan atau menggambarkan selanjutnya membandingkan antara data dengan peraturan perundang-undangan atau pendapat para ahli dan hasil analisis selanjutnya penulis diuraikan dalam bentuk kalimat yang sederhana dan sistematis.

\section{HASIL DAN PEMBAHASAN}

\section{Peran Lembaga Bantuan Hukum Perguruan Tinggi Yayasan Universitas Labuhan Batu}

Peran Lembaga bantuan hukum perguruan tinggi sangat dibutuhkan bagi masyarakt umum dalam hal dapat membantu dari aspek hukum terkait permasalahan-permasalahan yang berada ditengah-tengah masyarakat. Era globalisasi ini mengakibatkan banyaknya persoalan-persoalan masalah hukum yang dihadapi oleh masyarakat, peran dari lembaga bantuan hukum perguruan tinggi ini diharapkan oleh masyarakt agar dapat menjawab kebutuhan dari masyarakat yang ingin mencari keadilan. Lembaga bantuan hukum dalam pelayananya dapat berupa menangani (Perkara Litigasi dan Non litigasi) terkait Perkara Hukum Perdata, Hukum Pidana, Hukum Atministrasi negara dan pada intinya sesuai dengan kebutuhan dari masyarakat umum atau dapat dikatakan peran LBH harus dapat propisional dalam menjalankan tugasnya.

Adapun Lembaga Bantuan Hukum didirikan dengan konsep awal melindungi masyarakat dari penindasan hukum yang kerap menimpa mereka. Konsep ini kemudian dituangkan dalam Anggaran Dasar LBH yang didalamnya disebutkan bahwa Fungsi dan tujuan LBH adalah:

1. Memberi pelayanan hukum kepada rakyat miskin

2. Mengembangkan dan meningkatkan kesadaran hukum rakyat, terutama mengenai hakhaknya sebagai subjek hukum

3. Mengusahakan perubahan dan perbaikan hukum untuk mengisi kebutuhan baru dari masyarakat yang berkembang (Kadafi, 2002).

Mengenai pengaturan pemberian bantuan hukum bagi masyarakat yang tidak mampu untuk mencari keadilan diatur dalam:

1. Menurut Undang-undang dasar 1945

a. Pasal 1 ayat (3) mengenai, "Negara indonesia adalah negara hukum".

b. Pasal 27 ayat (1) mengenai, "Setiap Warga Negara bersamaan kedudukannya di dalam hukum dan pemerintahan wajib menjunjung hukum dan pemerintahan itu dengan tidak ada kecualinya

2. Menurut Undang-Undang Nomor 16 Tahun 2011 Tentang Bantuan Hukum

a. Pasal 4 ayat (1)

b. Pasal 5 ayat (1)

3. Menurut Undang-Undang Nomor 48 tahun 2009 tentang Pokok-Pokok Kekuasaan Kehakiman
a. Pasal 56 ayat (1)
b. Pasal 56 ayat (2)
c. Pasal 57 ayat (1)
d. Pasal 57 ayat (2)
e. Pasal 57 ayat (3)

4. Menurut Undang-Undang Nomor 18 Tahun 2003 Tentang Advokat.

a. Pasal 22 ayat (1)

b. Pasal 22 ayat (2)

5. Menurut Undang-Undang Nomor 8 Tahun 1981, bab VII KUHAP.
a. Pasal 69
b. Pasal 70 .

\section{KESIMPULAN DAN SARAN Kesimpulan}

Pada dasarnya Peran lembaga bantuan hukum Perguruan Tinggi Yayasan Universitas Labuhanbatu dapat membantu 
masyarakat yang kurang mampu dibidang permasalahan hukum, dalam hal ini peran dari LBH tersebut dapat memberikan manfaat yang besar kepada masyarakat, agar masyarakat mengetahui keberadaan dari pada LBH Perguruan tinggi tersebut. Maka perlu diadakan sosialisasi kesegalah lapisan masyarakat umum, lembaga bantuan hukum diatur didalam peraturan perundang-undangan diantaranya Undangundang Dasar 1945, undang-undang No. 16 tahun 2011, undang-undang No.48 Tahun 2009, Undang-undang No. 18 Tahun 2003, undang-undang No. 8 Tahun 1981. Lembaga bantuan hukum perguruan tinggi tersebut diharapkan dapat bermitra dengan Pemerintah dan instansi-instasi penegak hukum yang lain, guna menambah penunjang kenerja LBH yang lebih propisional dalam penegakan hukum.

\section{Saran}

Lembaga Bantuan Hukum Perguruan Tinggi Yayasan Universitas Labuhanbatu lebih aktif dalam memberikan bantuan hukum terhadap masyarakat yang membutuhkan pertolongan hukum, dalam penegakan hukum diharapkan propisional dan tidak membeda bedakan dari setiap masyarakat yang membutuhkan pertolongan hukum. Tegakkan hukum walaupun langit hari ini akan runtuh. Dalam menjalankan fungsi dan peranannya, Lembaga Bantuan Hukum perlu lebih turun ke masyarakat agar dapat lebih menyadarkan masyarakat akan hak-hak mereka dalam bantuan hukum

\section{DAFTAR PUSTAKA}

Abdurrahman. 1983. Aspek-Aspek Bantuan Hukum Di Indonesia. Cendana Press, Jakarta.

Harahap, Yahya. 2009. Pembahasan Dan Penerapan KUHAP: Penyidikan dan Penuntutan. Sinar Grafika, Jakarta.

Kadafi, Binziad dkk. 2002. Advokat Indonesia Mencari Legitimasi Studi Tentang Tanggung Jawab Profesi Hukum di Indonesia. Pusat Studi Hukum \& Kebijakan Indonesia, Jakarta.

Soekanto, Soerjono. 1985. Penelitaian Hukum Normatif. Rajawali, Jakarta.
Undang-Undang Dasar 1945

Undang-Undang Nomor 48 tahun 2009 tentang Pokok-Pokok Kekuasaan Kehakiman

Undang-Undang Nomor 18 Tahun 2003 Tentang Advokat.

Undang-Undang Nomor 16 Tahun 2011 Tentang Bantuan Hukum.

Undang-Undang Nomor 8 Tahun 1981 Tentang Hukum Acara Pidana

Winarta, Hendra. 2000. Bantuan Hukum: Suatu Hak Asasi Manusia Bukan Belas Kasihan. Elex Media Komputindo, Jakarta. 